\title{
PENGARUH KEDALAMAN TERHADAP NILAI PRODUKTIVITAS PRIMER DI WADUK JATIBARANG SEMARANG
}

\author{
The Influence of Depth on Primary Productivity in Jatibarang Reservoir, Semarang
}

\author{
Wiwi Siti Rohmah, Suryanti*), Max Rudolf Muskananfola
}

Program Studi Manajemen Sumberdaya Perairan

Fakultas Perikanan dan Ilmu Kelautan, Universitas Diponegoro

Jl. Prof. Soedarto, SH, Tembalang, Semarang, Jawa Tengah - 50275, Telp/Fax. +6224 7474698

Email : wiwi.rohmah93@gmail.com

\begin{abstract}
ABSTRAK
Waduk Jatibarang merupakan salah satu waduk yang tergolong baru di Kota Semarang. Untuk mencegah terjadinya penurunan kualitas perairan pada waduk dimasa mendatang, penting dilakukan pengukuran tingkat kesuburan perairan waduk secara berkala. Salah satu cara untuk mengetahui tingkat kesuburan perairan waduk yaitu dengan melakukan pengukuran produktivitas primer perairan dan kandungan klorofil-a serta parameter fisika-kimia perairan. Penelitian ini dilakukan pada bulan Februari-Maret 2016 di Waduk Jatibarang Semarang. Tujuan dari Penelitian ini adalah untuk mengetahui nilai produktivitas primer perairan berdasarkan perbedaan kedalaman serta untuk mengetahui pengaruh kedalaman terhadap nilai produktivitas primer perairan di Waduk Jatibarang, Semarang. Metode yang digunakan dalam penelitian ini adalah Deskriptif lokasi sampling, yaitu Stasiun I; Inlet, Stasiun II perairan tengah waduk dan Stasiun III Outlet dalam tiga kali pengulangan dengan rentang waktu satu minggu. Hasil pengukuran produktivitas primer pada ketiga stasiun per kedalaman adalah; kedalaman $0 \mathrm{~m}$ berkisar 54,750-90,000 $\mathrm{mgC} / \mathrm{m}^{3} /$ hari, kedalaman $5 \mathrm{~m}$ berkisar 91,500-102,750 $\mathrm{mgC} / \mathrm{m}^{3} / \mathrm{hari}$, kedalaman $10 \mathrm{~m}$ berkisar 39,750-64,500 $\mathrm{mgC} / \mathrm{m}^{3} /$ hari dan kedalaman $15 \mathrm{~m}$ berkisar 20,250-45,5000 $\mathrm{mgC} / \mathrm{m}^{3} /$ hari. Berdasarkan nilai tersebut maka perairan waduk Jatibarang tergolong sebagai perairan Mesotrofik-Eutrofik. Rata-rata nilai kandungan klorofil-a minggu ke-1 0,6913 mg/m³ minggu ke-2 $0,6665 \mathrm{mg} / \mathrm{m}^{3}$, dan minggu $\mathrm{ke}-30,4409 \mathrm{mg} / \mathrm{m}^{3}$. Hasil uji regresi sederhana menunjukan terdapat pengaruh variabel kedalaman dan kandungan klorofil-a terhadap produktivitas primer sebesar $51,3 \%$.
\end{abstract}

Kata Kunci : Produktivitas Primer; Klorofil-a; Waduk Jatibarang Semarang

\begin{abstract}
Jatibarang Reservoir is one of the new reservoirs in Semarang. To prevent the degradation of reservoirs water quality in the future, it is important to measure the dam water fertilization periodically. Like one of the ways to determine the level of fertility of the dam water is by measuring the primary productivity of the water and chlorophyll-a and physic-chemical parameters of the waters. This study was conducted from February to March 2016 in Semarang Jatibarang Reservoir. The aim of this study is to determine the primary productivity of waters based on depth difference and the depth effects on primary productivity of the waters of the Jatibarang reservoir, Semarang. The method used in this study is descriptive method. Sampling locations are station I; Inlet, Station II: middle of reservoir and stations III: Outlet with three repetitions for the period of one week. The results of primary productivity measurements at each stations per depth is; at the depth of $0 \mathrm{~m}$ the results ranges from 54.750 to $90.000 \mathrm{mgC} / \mathrm{m}^{3} / \mathrm{day}$, at the depth of $5 \mathrm{~m}$ from 91.500 to $102.750 \mathrm{mgC} / \mathrm{m}^{3} / \mathrm{day}$, at the depth of $10 \mathrm{~m}$ from 39.750 to $64.500 \mathrm{mgC/m3/day}$ and at the depth of $15 \mathrm{~m}$ from 20.250 to 45.5000 $\mathrm{mgCl} \mathrm{m}^{3} /$ day. Based on these results, it is concluded that the water of Jatibarang Reservoir is classified as Mesotrofik-eutrophic waters. The average value of chlorophyll-a in the first week is $0.6913 \mathrm{mg} / \mathrm{m}^{3}$, in the $2 \mathrm{nd}$ week is $0.6665 \mathrm{mg} / \mathrm{m}^{3}$, and the $3 \mathrm{rd}$ week is $0.4409 \mathrm{mg} / \mathrm{m}^{3}$. The results of simple regression test reveals that there is a significant effect of water depth and chlorophyll-a on primary productivity is $51.3 \%$.
\end{abstract}

Keywords: Primary Productivity, Chlorophyll-a, Jatibarang Reservoir Semarang

*) Penulis penanggungjawab

${ }^{\circledR}$ Copyright by Management of Aquatic Resources (MAQUARES) 


\section{PENDAHULUAN}

Waduk Jatibarang merupakan waduk yang baru beroperasi selama tiga tahun. Sehingga informasi mengenai nilai produktivitas primer dalam perairan penting diketahui terkait dengan kelayakan habitat untuk kehidupan organisme akuatik didalamnya. Keberadaan produtivitas primer mempunyai peranan penting bagi lingkungan perairan yaitu sebagai penyedia oksigen terlarut dan penyedia makanan oleh fitoplankton dalam ekosistem perairan.

Produktivitas primer dari suatu ekosistem didefinisikan sebagai jumlah energi cahaya yang diserap dan kemudian disimpan oleh organisme-organisme produser melalui kegiatan fotosintesis dan kemosintesis dalam suatu periode waktu tertentu (Widianingsih, 2002).

Pengukuran kandungan klorofil-a fitoplankton merupakan salah satu alat pengukuran kesuburan suatu perairan yang dinyatakan dalam bentuk produktivitas primer. Klorofil-a fitoplankton adalah suatu pigmen aktif dalam sel tumbuhan yang mempunyai peran penting dalam berlangsungnya proses fotosintesis perairan (Sediadi dan Edward, 1993).

Waduk merupakan perairan yang tenang (lentik), sehingga tingginya aktivitas penduduk disekitar waduk akan menyebabkan beban masukan berupa limbah pertanian (pestisida), limbah rumah tangga (domestik) serta limbah dari aktivitas wisata yang berada ditengah-tengah waduk semakin tinggi. Sehingga menyebabkan terjadinya perubahan fisik kimia yang akan mempengaruhi produktivitas primer perairan. Selain itu tingginya nilai produktivitas primer juga dipengaruhi oleh kedalaman dan kandungan klorofil-a dalam perairan. Kedalaman suatu perairan akan berpengaruh terhadap masuknya cahaya matahari kedalam perairan tersebut, semakin dalam perairan maka akan berpengaruh pada kemampuan fitoplankton dalam berfotosintesis. Hal ini akan mempengaruhi nilai produktivitas primer dalam perairan, sehingga penelitian ini sangat penting dilakukan untuk mengetahui pengaruh kedalaman dan kandungan klorofil-a suatu perairan dapat berpengaruh terhadap nilai produktivitas primer di waduk Jatibarang.

Tujuan dari penelitian ini adalah untuk mengetahui nilai produktivitas primer perairan berdasarkan perbedaan kedalaman yang berbeda dengan menggunakan metode oksigen (botol gelap-botol terang) serta untuk mengetahui pengaruh kedalaman terhadap nilai produktivitas primer perairan di Waduk Jatibarang, Semarang.

\section{MATERI DAN METODE PENELITIAN}

Penelitian ini dilaksanakan pada bulan Februari - Maret 2016 di Waduk Jatibarang. Metode penelitian yang digunakan dalam penelitian ini adalah deskriptif dan metode pengambilan sampel dilakukan secara Purposive sampling berdasarlam perbedaan aktivitas diarea waduk yang dibagi menjadi 3 stasiun. Pada setiap stasiun dilakukan pengambilan sampel dengan perbedaan kedalaman, yaitu $0 \mathrm{~m}, 5 \mathrm{~m}, 10 \mathrm{~m}$ dan $15 \mathrm{~m}$. Penelitian ini dilaksanakan sebanyak tiga kali pengulangan dengan rentan waktu satu minggu.

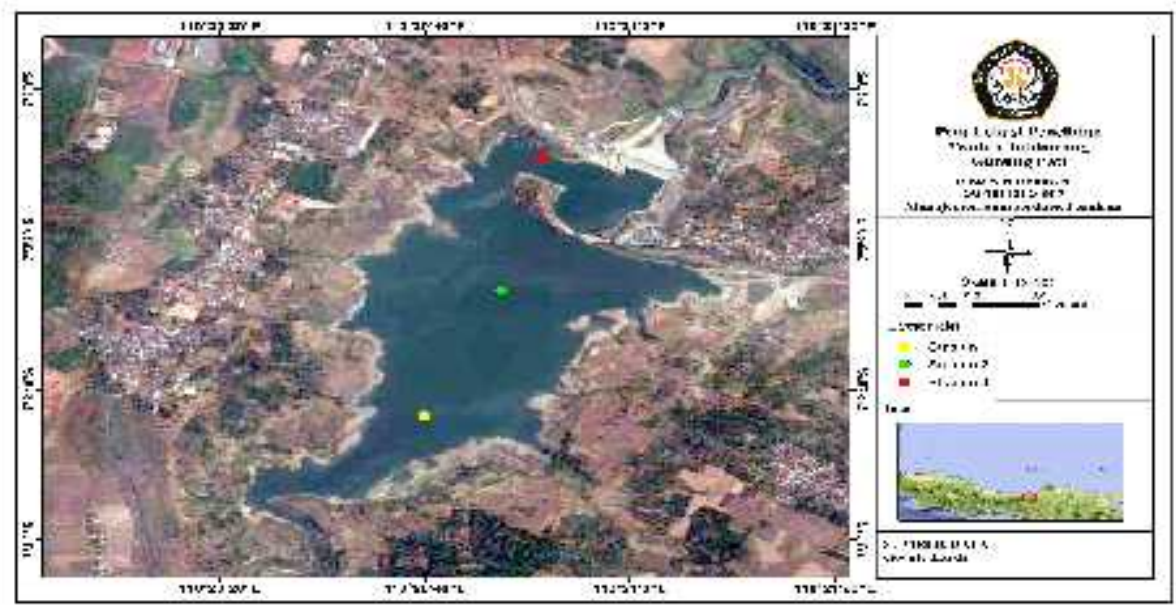

Gambar 1. Lokasi Penelitian Waduk Jatibarang

Pengukuran nilai produktivitas dilakukan dengan menggunakan metode oksigen (botol gelap-botol terang). Sampel air dimasukkan kedalam botol Winkler gelap dan terang dengan volume yang sama, kemudian diinkubasi selama 6 jam berdasarkan stasiun dan kedalaman yang sudah ditentukan. Sebelum diinkubasi, sampel air terlebih dahulu diukur oksigen terlarutnya sebagai DO awal. Pengambilan sampel air berdasarkan kedalaman dengan menggunakan botol Nensen $2 \ell$. Setelah masa inkubasi berakhir, botol diangkat keluar dan diukur kembali kadar oksigen terlarutnya sebagai DO akhir. Untuk menghitung produktivitas primer kotor dihitung menggunakan rumus Umaly dan Culvin (1998), dengan rumus sebagai berikut: 


$$
\mathrm{FB}=\frac{\mathrm{BT}-\mathrm{BG} \times 0,375 \times 1000}{\mathrm{t} \times \mathrm{PQ}}
$$

Keterangan:

FB = Produktivitas primer kotor $\left(\mathrm{mgC} / \mathrm{m}^{3} / \mathrm{jam}\right)$

BT = konsentrasi oksigen terlarut dalam botol telap $(\mathrm{mg} / \mathrm{l})$

BG = konsentrasi oksigen terlarut dalam botol gelap $(\mathrm{mg} / \mathrm{l})$

$\mathrm{t} \quad=$ Waktu inkubasi (Jam)

$0,375=$ Faktor konversi dari oksigen terlarut ke karbon

$\mathrm{PQ} \quad=$ Koefisien fotosintesis $(1,2)$

Menurut Barus et al., (2008), Untuk mengubah nilai $\mathrm{mg} / \mathrm{l}$ menjadi $\mathrm{mgC} / \mathrm{m}^{3}$ maka nilai dalam $\mathrm{mg} / \mathrm{l}$ dikalikan dengan faktor 375,36 . Hal ini untuk menghasilkan $\mathrm{mgC} / \mathrm{m}^{3}$. Untuk mendapatkan nilai produktivitas primer dalam satuan hari maka nilai per jam harus dikalikan dengan 12 (secara teori cahaya matahari hanya diperoleh selama 12 jam per hari).

Pengambilan sampel air untuk analisis kandungan klorofil berdasarkan perbedaan kedalaman dengan menggunakan botol nensen yang dimasukkan kedalam botol plastik volume $1.5 \ell$, kemudian dilakukan penyaringan menggunakan kertas saring halus dan dibungkus alumunium foil. Sampel yang telah disaring selanjutnya di analisis menggunakan specktrofotometer. Perhitungan klorofil-a dihitung dengan rumus yang dikemukakan oleh Parsons et al., (1984), yaitu:

Keterangan:

$$
\text { Klorofil } \mathrm{mg} / \mathrm{m}^{3}=\frac{\mathrm{Ca} \times \mathrm{Va}}{\mathrm{V} \times \mathrm{d}}
$$

$\mathrm{Ca}=$ Nilai klorofil $(11,85 \times \mathrm{E} 664)-(1,54 \times \mathrm{E} 647)-(0,08 \times \mathrm{E} 630)$

$\mathrm{Va} \quad=$ Volume aseton $90 \%(15 \mathrm{ml})$

$\mathrm{d} \quad=$ Diameter cuvet $(10)$

$\mathrm{V} \quad=$ Sampel air $(1500 \mathrm{ml})$

Pengukuran parameter fisika-kimia pendukung dilakukan secara in situ pada masing-masing stasiun. Tujuan pengukuran parameter pendukung adalah untuk memberikan gambaran kondisi perairan waduk Jatibarang saat melakukan penelitian. Pengukuran parameter pendukung tersaji dalam Tabel 1.

Tabel 1. Parameter Fisika-Kimia

\begin{tabular}{llll}
\hline No & Parameter & Satuan & Alat \\
\hline 1 & Suhu Air dan Suhu Udara & ${ }^{\circ} \mathrm{C}$ & Termometer \\
2 & Kecerahan & $\mathrm{cm}$ & Secchi disk \\
3 & Kedalaman Total & $\mathrm{m}$ & Jangkar bertali \\
4 & $\mathrm{pH}$ & - & pH paper \\
5 & Intensitas cahaya & $\mathrm{Lux}$ & Lux meter \\
6 & Oksigen terlarut (DO) & $\mathrm{mg} / \mathrm{l}$ & Titrasi \\
7 & Karbondioksida (CO2) perairan & $\mathrm{mg} / \mathrm{l}$ & Tirtrasi \\
\hline
\end{tabular}

Sumber: Penelitian 2016

\section{HASIL DAN PEMBAHASAN}

Hasil

Waduk Jatibarang Semarang merupakan waduk yang baru beroperasi selama kurang lebih tiga tahun semenjak diresmikan pada tahun 2014. Waduk serbaguna Jatibarang terletak di daerah Gunungpati Semarang, memiliki luas $189 \mathrm{Ha}$ dengan luas daerah tangkapan $54 \mathrm{~km}^{2}$ serta dapat menampung $\pm 20,4$ juta $\mathrm{m}^{3}$ air sungai Kreo (KPU, 2015). Fungsi serbaguna Waduk Jatibarang yaitu sebagai pencegah banjir, pemasok air irigasi, kegiatan perikanan, pariwisata, penyedia air rumah tangga dan industri. Secara geografis posisi koordinat lokasi pengambilan sampel tersaji pada Tabel 2.

Tabel 2. Plot Titik Koordinat Stasiun Pengambilan Sampel

\begin{tabular}{clc}
\hline Stasiun & \multicolumn{1}{c}{ Titik Koordinat } & Lokasi \\
\hline \multirow{2}{*}{ I } & $\mathrm{S}: 7^{\circ} 02^{\prime} 43.6^{\prime \prime}$ & Inlet (masukkan dari sungai Kreo) \\
& $\mathrm{E}: 110^{\circ} 20^{\prime} 40.3^{\prime \prime}$ & \\
$\mathrm{S}: 7^{\circ} 02^{\prime} 27.2^{\prime \prime}$ & Tengah waduk (terdapat objek wisata gua Kreo) \\
$\mathrm{II}$ & $\mathrm{E}: 7^{\circ} 00^{\circ} 090^{\prime} 47.8^{\prime \prime}$ & \\
& $\mathrm{E}: 110^{\circ} 20^{\prime} 51.5^{\prime \prime}$ & Outlet (setelah objek wisata gua Kreo)
\end{tabular}

Sumber: Penelitian 2016

${ }^{\circledR}$ Copyright by Management of Aquatic Resources (MAQUARES) 


\section{Produktivitas Primer}

Hasil pengukuran Produktivitas primer perairan di Waduk Jatibarang berdasarkan kedalaman tersaji pada Gambar 2. Berdasarkan hasil pengukuran tersebut, nilai produktivitas primer tertinggi rata-rata terdapat pada kedalaman 4-5 meter pada ketiga stasiun dan nilai terendah rata-rata terdapat pada kedalaman 10-15 meter.

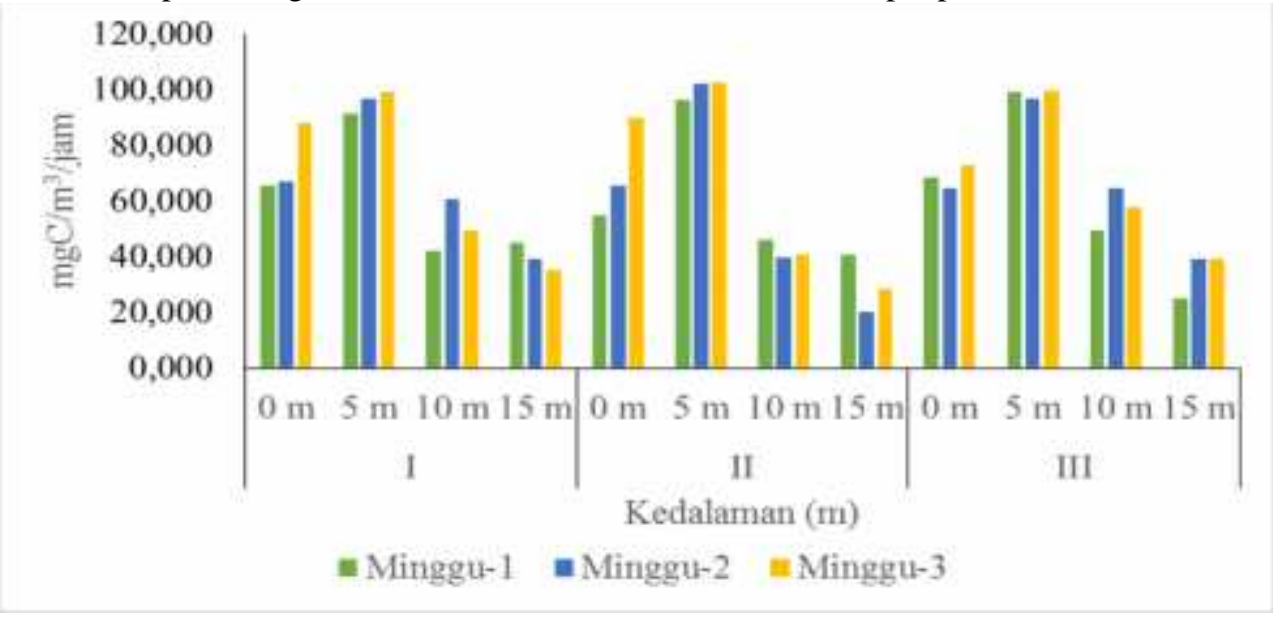

Gambar 2. Nilai Produktivitas Primer

Tabel 3. Konversi Nilai Produktivitas Primer Per Jam ke Per Hari

\begin{tabular}{|c|c|c|c|c|c|c|c|}
\hline \multirow[b]{2}{*}{ Stasiun } & \multirow[b]{2}{*}{$\begin{array}{c}\text { Kedalama } \\
\mathbf{n}(\mathbf{m})\end{array}$} & \multicolumn{3}{|c|}{$\mathrm{mgC} / \mathrm{m}^{3} / \mathrm{jam}$} & \multicolumn{3}{|c|}{$\mathrm{mgC} / \mathrm{m}^{3} /$ Hari } \\
\hline & & $\underset{1}{\text { Minggu }}$ & $\underset{2}{\text { Minggu }}$ & $\begin{array}{c}\text { Minggu } \\
\mathbf{3}\end{array}$ & $\begin{array}{c}\text { Minggu } \\
1\end{array}$ & $\underset{2}{\text { Minggu }}$ & $\begin{array}{c}\text { Minggu } \\
\mathbf{3}\end{array}$ \\
\hline \multirow{4}{*}{ I } & 0 & 65,250 & 66,750 & 87,750 & 783 & 801 & 1053 \\
\hline & 5 & 91,500 & 96,750 & 99,000 & 1098 & 1161 & 1188 \\
\hline & 10 & 42,000 & 60,750 & 49,500 & 504 & 729 & 594 \\
\hline & 15 & 45,000 & 39,000 & 35,250 & 540 & 468 & 423 \\
\hline \multirow{4}{*}{ II } & 0 & 54,750 & 65,250 & 90,000 & 657 & 783 & 1080 \\
\hline & 5 & 96,000 & 102,000 & 102,750 & 1152 & 1224 & 1233 \\
\hline & 10 & 45,750 & 39,750 & 40,500 & 549 & 477 & 486 \\
\hline & 15 & 40,500 & 20,250 & 28,500 & 486 & 243 & 342 \\
\hline \multirow{4}{*}{ III } & 0 & 68,500 & 64,500 & 72,750 & 822 & 774 & 873 \\
\hline & 5 & 99,250 & 96,750 & 99,750 & 1191 & 1161 & 1197 \\
\hline & 10 & 49,500 & 64,500 & 57,750 & 594 & 774 & 693 \\
\hline & 15 & 24,750 & 39,000 & 39,000 & 297 & 468 & 468 \\
\hline
\end{tabular}

Sumber: Penelitian 2016

\section{Kandungan Klorofil-a}

Hasil pengukuran kandungan klorofil-a berdasarkan kedalaman di Waduk Jatibarang Semarang tersaji pada Tabel 4.

Tabel 4. Hasil Pengukuran Kandungan Klorofil-a

\begin{tabular}{|c|c|c|c|c|}
\hline \multirow{2}{*}{ Stasiun } & \multirow{2}{*}{ Kedalaman (m) } & \multicolumn{3}{|c|}{ Klorofil-a mg/m ${ }^{3}$} \\
\hline & & Minggu 1 & Minggu 2 & Minggu 3 \\
\hline \multirow[t]{4}{*}{ I } & 0 & 0,9762 & 1,7603 & 0,0798 \\
\hline & 5 & 1,1818 & 0,8957 & 1,5564 \\
\hline & 10 & 0,7031 & 0,3191 & 0,4667 \\
\hline & 15 & 0,3429 & 0,0696 & 0,2054 \\
\hline \multirow[t]{4}{*}{ II } & 0 & 0,9438 & 0,4106 & 0,6705 \\
\hline & 5 & 1,6306 & 1,0456 & 1,0661 \\
\hline & 10 & 0,4108 & 0,1802 & 0,3429 \\
\hline & 15 & 0,1153 & 0,1375 & 0,2054 \\
\hline \multirow[t]{4}{*}{ III } & 0 & 0,1817 & 0,7249 & 0,9517 \\
\hline & 5 & 0,3412 & 1,0731 & 0,5923 \\
\hline & 10 & 0,6808 & 0,0814 & 0,2852 \\
\hline & 15 & 0,2274 & 0,0696 & 0,0813 \\
\hline
\end{tabular}

Sumber: Penelitian 2016

\footnotetext{
${ }^{\circ}$ Copyright by Management of Aquatic Resources (MAQUARES)
} 


\section{Parameter Fisika-Kimia}

Hasil pengukuran parameter fisika-kimia pendukung di Waduk Jatibarang tersaji pada Tabel 5.

Tabel 5. Hasil Pengukuran Parameter Fisika-Kimia selama Penelitian

\begin{tabular}{|c|c|c|c|c|c|c|c|c|}
\hline \multirow[b]{2}{*}{$\begin{array}{c}\text { Stasiu } \\
\mathbf{n}\end{array}$} & \multirow[b]{2}{*}{$\begin{array}{c}\text { Kedalama } \\
\mathbf{n}(\mathbf{m})\end{array}$} & \multicolumn{7}{|c|}{ Parameter Fisika - Kimia } \\
\hline & & $\begin{array}{c}\text { Suhu } \\
\text { Udara } \\
{ }^{\circ} \mathbf{C} \\
\end{array}$ & $\begin{array}{c}\text { Suhu } \\
\text { Air } \\
{ }^{\circ} \mathbf{C}\end{array}$ & $\begin{array}{c}\text { Keceraha } \\
\mathbf{n}(\mathbf{c m})\end{array}$ & $\begin{array}{c}\text { Kedalama } \\
\text { n Total } \\
(\mathbf{m})\end{array}$ & pH & $\begin{array}{c}\mathrm{CO}_{2} \\
(\mathrm{mg} / \mathrm{l})\end{array}$ & $\begin{array}{c}\text { DO } \\
(\mathrm{mg} / \mathrm{l})\end{array}$ \\
\hline \multirow{4}{*}{ I } & $0 \mathrm{~m}$ & $30-31$ & $31-32$ & $41,5-55,5$ & 35 & $6-7$ & 0 & $7,8-8$ \\
\hline & $5 \mathrm{~m}$ & & $27-29$ & & & $6-7$ & $3,3-3,74$ & $4,68-7,67$ \\
\hline & $10 \mathrm{~m}$ & & $26-28$ & & & $6-7$ & $4,4-6,6$ & $3,8-5,4$ \\
\hline & $15 \mathrm{~m}$ & & $26-28$ & & & $6-7$ & $5,06-8$ & $2-4,12$ \\
\hline \multirow{4}{*}{ II } & $0 \mathrm{~m}$ & $30-31$ & $29-32$ & $50-65,7$ & 36 & $6-7$ & 0 & $7,44-7,8$ \\
\hline & $5 \mathrm{~m}$ & & $26-29$ & & & $6-7$ & $3,54-5,06$ & $5,6-6,4$ \\
\hline & $10 \mathrm{~m}$ & & $26-28$ & & & $6-7$ & $4,84-6,82$ & $4,02-4,78$ \\
\hline & $15 \mathrm{~m}$ & & $26-27$ & & & $6-7$ & $7,26-8,8$ & $2,52-3,44$ \\
\hline \multirow{4}{*}{ III } & $0 \mathrm{~m}$ & $30-31$ & $31-32$ & $44-45$ & 28 & $6-7$ & 0 & $7,5-8$ \\
\hline & $5 \mathrm{~m}$ & & $27-29$ & & & $6-7$ & $3,3-3,86$ & $4,36-7,68$ \\
\hline & $10 \mathrm{~m}$ & & $27-28$ & & & $6-7$ & $5,06-6,6$ & $3-5,4$ \\
\hline & $15 \mathrm{~m}$ & & $26-27$ & & & $6-7$ & $8-8,8$ & $2-3,8$ \\
\hline
\end{tabular}

Sumber: Penelitian 2016

\section{Pembahasan \\ Produktivitas Primer}

Hasil pengukuran produktivitas primer perairan di waduk Jatibarang sebanyak tiga kali pengulangan pada setiap stasiun adalah, stasiun I berkisar antara $423-1188 \mathrm{mgC} / \mathrm{m}^{3} / \mathrm{hari}$, stasiun II $243-1233 \mathrm{mgC} / \mathrm{m}^{3} / \mathrm{hari}$ dan stasiun III $297-1197 \mathrm{mgC} / \mathrm{m}^{3} /$ hari. Berdasarkan nilai rata-rata produktivitas primer yang diperoleh selama penelitian, maka perairan waduk Jatibarang dapat dikategorikan sebagai perairan Mesotrofik-Eutrofik, hal itu dapat dilihat dari nilai produktivitas primer yang terkandung didalamnya penggolongan tersebut berdasarkan Wetzel (1983). Perairan dikatakan eutrofik jika memiliki nutrien tinggi dan mendukung tumbuhan dan hewan air yang hidup didalamnya. Menurut Effendi (2003), mesotrofik adalah perairan yang memiliki unsur hara dan produktivitas sedang (produktivitas primer dan biomassa sedang).

Nilai tertinggi produktivitas primer perairan rata-rata terdapat pada kedalaman 5 meter pada ke tiga stasiun, yaitu berkisar antara $1098-1224 \mathrm{mgC} / \mathrm{m}^{3} / \mathrm{hari}$. Nilai tertinggi terdapat pada stasiun II sebesar 1224 $\mathrm{mgC} / \mathrm{m}^{3} /$ hari. Sedangkan nilai produktivitas primer terendah rata-rata terdapat pada kedalaman 15 meter dari ketiga stasiun, nilai terendah terdapat pada stasiun II sebesar $243 \mathrm{mgC} / \mathrm{m}^{3} /$ hari. Tingginya nilai produktivitas primer pada permukaan hingga kedalaman 5 meter dan rendahnya nilai produktivitas primer pada kedalaman 15 meter dapat disebabkan oleh beberapa faktor, salah satunya adalah keberadaan intensitas cahaya yang tersedia dalam jumlah maksimal hingga mampu mencapai kedalaman 5 meter. Hal ini diperkuat oleh Hutabarat (2000), cahaya sangat dibutuhkan oleh fitoplankton untuk pertumbuhan serta membantu proses fotosintesa. Cahaya akan semakin berkurang intensitasnya dengan makin besarnya kedalaman perairan. Oleh karena itu fitoplankton umumnya banyak dijumpai pada kedalaman 0 sampai 250 meter. Di atas kedalaman ini sinar matahari sudah tidak efisien lagi, sehingga proses fotosintesa terhambat. Akibatnya bahan-bahan organik yang dihasilkan (gross production) menjadi berkurang.

Perbedaan nilai produktivitas primer yang mencolok pada ketiga stasiun dapat dilihat berdasarkan kedalaman 5 meter hingga 15 meter, dimana nilai produktivitas primer berkurang seiring dengan bertambahnya kedalaman, hal ini karena intensitas cahaya yang masuk semakin berkurang. Intensitas cahaya berkurang seiring dengan bertambahnya kedalaman. Hal ini sesuai dengan pendapat Wetzel dan Likens (1991), intensitas cahaya berkurang secara eksponensial sejalan dengan bertambahnya kedalaman air. Berkurangnya intensitas cahaya secara eksponensial disebut sebagai atenuasi, yang disebabkan oleh adanya proses penyerapan dan penyebaran.

\section{Kandungan Klorofil-a}

Hasil pengujian dari air sampel waduk Jatibarang sebanyak tiga kali pengulangan menunjukkan nilai klorofil-a berkisar antara $0,0696-1,6306 \mathrm{mg} / \mathrm{m}^{3}$. Kandungan klorofil-a tertinggi terdapat pada stasiun II kedalaman 5 meter sebesar $1,6306 \mathrm{mg} / \mathrm{m}^{3}$, sedangkan nilai terendah terdapat pada stasiun I dan III kedalaman 15 meter sebesar $0,0696 \mathrm{mg} / \mathrm{m}^{3}$. Nilai klorofil-a yang diperoleh sebenarnya masih terlalu kecil bagi perairan waduk, namun jika dibandingkan dengan nilai produktivitas primer yang dihasilkan hal itu sesuai dimana nilai produktivitas primer sejalan dengan kandungan klorofil.

Kandungan klorofil-a tertinggi terdapat pada stasiun II kedalaman 5 meter sebesar 1,6306 mg/m $\mathrm{m}^{3}$ dan nilai produktivitas primer pada stasiun dan kedalaman yang sama yaitu sebesar $1224 \mathrm{mgC} / \mathrm{m}^{3} / \mathrm{hari}$, nilai tersebut

\footnotetext{
${ }^{\circledR}$ Copyright by Management of Aquatic Resources (MAQUARES)
} 
merupakan nilai produktivitas primer tertinggi. Maka dapat disimpulkan bahwa tingginya kandungan klorofil-a menghasilkan nilai produktivitas primer yang tinggi. Hal tersebut dijelaskan oleh Sitorus (2009), peningkatan nilai produktivitas primer merupakan hasil proses fotosintesis sebanding dengan jumlah oksigen yang dihasilkan, dan kandungan oksigen terlarut di perairan dapat memberikan petunjuk tentang tingginya produktivitas primer disuatu perairan. Klorofil-a merupakan salah satu parameter yang sangat menentukan produktivitas primer di danau, dimana kelimpahan fitoplankton yang tinggi akan menghasilkan oksigen yang lebih banyak jika dibandingkan dengan kelimpahan fitoplankton yang rendah, artinya kelimpahan fitoplankton yang tinggi cenderung menghasilkan oksigen yang tinggi sebagai hasil dari proses fotosintesis.

\section{Pengaruh Kedalaman dan Kandungan Klorofil-a terhadap Nilai Produktivitas Primer}

Hasil uji Regresi sederhana menggunakan Software Microsoft Excel 2013 tersaji pada Tabel 6.

Tabel 6. Hasil Uji Regresi Sederhana

Sumber: Penelitian 2016

\begin{tabular}{cccc}
\hline Persamaan & R & $\mathbf{R}^{\mathbf{2}}$ & Sig \\
\hline $\mathrm{Y}=86,789-3,1256 \mathrm{x}$ & 0,7166 & 0,5135 & 0,008 \\
\hline
\end{tabular}

Berdasarkan data pada Tabel 7 diperoleh nilai koefisien korelasi (R) sebesar 0,7166 dan nilai koefisien determinasi $\left(R^{2}\right)$ sebesar 0,5135 dengan persamaan regresi $Y=86,789-3,1256 x$. Data hasil uji regresi dengan analisis varian menunjukkan bahwa nilai signifikasi 0,008 yang berarti lebih kecil dari nilai probabilitas 0,05 atau dapat ditulis $0,008<0,05$. Artinya bahwa signifikasi $<0,05$ terdapat pengaruh kedalaman terhadap produktivitas primer perairan waduk Jatibarang.

Uji signifikasi koefisien korelasi disajikan pada Tabel 7, diperoleh koefisien korelasi (R) sebesar 0,7166 dan Fhit $=10,553$, dengan $\mathrm{p}$-value $=0,008<0,05$. Hal ini bermakna H0 ditolak, artinya koefisien korelasi $\mathrm{X}$ dan $\mathrm{Y}$ adalah berarti atau signifikan. Sedangkan koefisien determinasi $\left(\mathrm{R}^{2}\right)$ dari tabel diatas sebesar 0,5135 yang mengandung makna bahwa sebesar 51,3\% variasi variabel produktivitas primer dipengaruh oleh variabel kedalaman.

Hasil uji regresi yang diperoleh membuktikan bahwa tingginya nilai produktivitas primer pada permukaan hingga kedalaman 5 meter sangat dipengaruhi oleh klorofil-a dimana nilai klorofil-a tertinggi rata-rata terdapat pada kedalaman tersebut. Hal ini disebabkan oleh keberadaan intensitas cahaya matahari yang masuk kedalam perairan berada dalam jumlah maksimal, sehingga proses fotosintesis berlangsung baik tanpa ada hambatan. Menurut Alianto et al., (2007) dalam Eko (2015), produktivitas primer sangat dipengaruhi oleh klorofil-a dan menunjukkan hubungan yang berkorelasi positif dengan produktivitas primer.

Produktivitas primer dipengaruhi oleh variabel kedalaman sebesar 51,3\%, maka dapat diasumsikan bahwa sebesar $49 \%$ keberadaan produktivitas primer diperairan dapat dipengaruhi oleh berbagai faktor lain seperti suhu, intensitas cahaya, kekeruhan dan sebagainya. Hal ini sesuai dengan pendapat Asriyana dan Yuliana (2012), faktor-faktor yang mempengaruhi produktivitas primer perairan antara lain; suhu, cahaya, zat hara, derajat keasaman $(\mathrm{pH})$, turbulensi dan kedalaman kritis serta berkurangnya pemangsaan.

\section{KESIMPULAN}

Berdasarkan hasil penelitian, kesimpulan yang dapat diperoleh adalah:

Nilai produktivitas primer di Waduk Jatibarang pada ketiga stasiun dengan kedalaman 0, 5, 10 dan $15 \mathrm{~m}$ berturut-turut adalah; berkisar 54,750-90,000, 91,500-102,750, 39,750-64,500 dan 20,250-45,5000 $\mathrm{mgC} / \mathrm{m}^{3} /$ hari, maka perairan waduk Jatibarang dapat dikategorikan perairan Mesotrofik-Eutrofik, sedangkan hasil uji regresi sederhana menunjukan sebesar 51,3\% variabilitas variabel produktivitas primer terdapat pengaruh kedalaman secara bersama-sama terhadap produktivitas primer sebesar $51,3 \%$ dan sisanya dapat dipengaruh oleh faktor lain.

\section{DAFTAR PUSTAKA}

Asriyana dan Yuliana. 2012. Produktivitas Perairan. Bumi Aksara. Jakarta.

Barus T.A. S. S. Sinaga, dan R. Tarigan 2008. Produktivitas Primer Fitoplankton dan Hubungannya dengan Faktor Fisik-Kimia Air di Perairan Parapat, Danau Toba. Jurnal Biologi. Universitas Sumatera Utara. $3(1): 11-16$

Effendi, H. 2003. Telaah Kualitas Air bagi Pengelolaan Sumber Daya dan Lingkungan Perairan. Kanisius, Yogyakarta

Eko, N. S. 2015. Produktivitas Primer dan Kelimpahan Fitoplankton pada Area yang berbeda di Sungai Betahwalang, Kabupaten Demak. Universitas Diponegoro. Semarang 
Hutabarat, S. 2000. Produktivitas Perairan dan Plankton. Telaah terhadap ilmu Perikanan dan Kelautan. Universitas Diponegoro. Semarang

Kadir. 2015. Statistika Terapan. Konsep contoh dan Analisis Data dengan Program SPSS / Lisrel dalam Penelitian. Raja Grafindo Persada. Jakarta

Parsons, T. R., M. Takeshi and B. Hagrave. 1984. Biological Oceanographic Processes, Third Edition. Oxford. Pergamon Press. Great Britain

Sediadi, A. dan Edward. 1993. Kandungan Klorofil-a Fitoplankton di Perairan Pulau-pulau Lease Maluku Tengah. Puslitbang Oseanografi LIPI. Jakarta

Sitorus, M. 2009. Hubungan Nilai Produktivitas Primer dengan Konsentrasi Klorofil a, dan Faktor Fisik Kimia di Perairan Danau Toba, Balige. Sumatera Utara.

Umaly, R. C. and L. A. Cuvin. 1988. Limnology : Laboratory and Field Guide Physico-Chemical Factors, Biology Factors. National Book Store Publ. Manila. 179 p

Wetzel, R. G. and Likens G.E. 1991. Limnological Analysis. Second Edition. Springer Verlag. New York. 1983. Limnology. Sounders Company. Philadelphia.

Widianingsih, N. 2002. Produktivitas Primer Fitoplankton Tambak Udang (Penaeus monodon) di Desa Ayah Kabupaten Kebumen. Purwokerto.

Http://www.pu.go.id/berita/10190/Waduk-Jatibarang-Semarang-Di-Operasionalkan 